http://dx.doi.org/10.18542/mri.v14i23.9658

\title{
O ENSINO RELIGIOSO NA REDE ESTADUAL DE EDUCAÇÃO DO AMAZONAS: PRIMEIRAS OBSERVAÇÕES EM UM CAMPO NOVO
}

\author{
RELIGIOUS TEACHING IN THE AMAZONAS STATE EDUCATION NETWORK: FIRST \\ OBSERVATIONS IN A NEW FIELD
}

\begin{abstract}
Resumo: Este artigo, configura-se como um trabalho preliminar acerca da oferta do Ensino Religioso no Estado do Amazonas e debruçou-se sobre os aspectos legais da disciplina a nível nacional e estadual. Para a produção do mesmo consultei os documentos de caráter normativo ligados a esta disciplina a nível estadual, comparando-os a legislação nacional e outros documentos relacionados a fim de encontrar convergências e divergências entre eles. Nesse processo de aproximação, percebe-se que o Ensino Religioso no Amazonas retrocedeu na forma de admissão de professores em relação as discussões travadas a nível nacional e que ficou ainda mais discrepante com o recente parecer do Conselho Nacional de Educação que estabelece a Licenciatura em Ciência(s) da(s) Religião(ões) como a formação do professor de Ensino Religioso no Brasil.
\end{abstract}

Palavras-chave: Ensino Religioso. Amazonas. Lesgislação.
Manoel Vitor BARBOSA NETO ${ }^{1}$

Universidade do Estado do Pará (UEPA)

\begin{abstract}
This article is configured as a preliminary work on the provision of Religious Education in the State of Amazonas and focused on the legal aspects of the discipline at national and state level. For its production, I consulted the normative documents related to this discipline at the state level, comparing them to national legislation and other related documents in order to find convergences and divergences between them. In this process of approximation, it can be seen that Religious Education in Amazonas went back in the form of admission of teachers in relation to the discussions held at the national level and that it was even more inconsistent with the recent opinion of the National Council of Education establishing the Degree in Science (s) of Religion (s) as the formation of the teacher of Religious Education in Brazil.
\end{abstract}

Keywords: Religious Education. Amazonas. Legislation.

\footnotetext{
${ }^{1}$ Mestre em Ciências da Religião (UEPA). E-mail: neto_barbosa28@outlook.com
} 


\section{INTRODUÇÃO}

Este trabalho é resultado dos primeiros meses de observação sobre o Ensino Religioso na rede estadual de educação do Estado do Amazonas. Esta escolha não foi aleatória, mas como consequencia do meu processo de inserção neste campo através do exercício da docência que até o momento venho realizando. Face a exposto, entendo ser necessário esclarecer três elementos que considero fundamentais para que o leitor, ao entrar em contato com esta produção, possa tirar o melhor proveito possível da mesma, ao mesmo tempo que fique bem informado sobre sua abrangência.

O primeiro elemento a ser informado é que este trabalho se configura como um esforço preliminar, por isso, as informações aqui terão caráter introdutório e será priorizado as questões legais que envolve o Ensino Religioso, apontando como esses elementos estão dispostos na rede estadual de educação do Amazonas. O segundo elemento a ser esclarecido é que não se trata de um trabalho

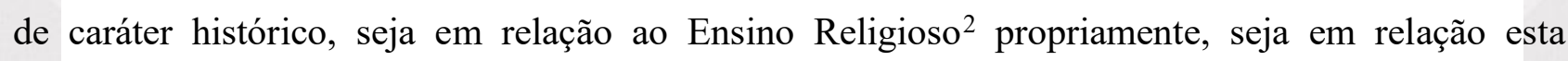
disciplina e sua trajetória no Amazonas.

O terceiro e último ponto que é importante frisar, se refere a compreensão de não ler este trabalho com tendo um tom ufanista por enfatizar a legislação como se a existência dela, se apenas a homologação da lei fosse o suficiente para que determinada realidade fosse alterada em uma espécie de "mágica", no entanto, não se pode desconsiderar que toda e qualquer lei é fruto de um processo histórico que envolve pessoas e grupos que reivindicam a alteração de determinada realidade, bem como, sabemos, e isso, qualquer manual de direito administrativo informa, que a ação do agente público gira em torno do que a lei determina, portanto, a legislação, apesar das contradições que possam ser vista na realidade é um elemento que não pode ser desconsiderado nas reflexões sobre o Ensino Religioso.

Apontamentos devidamente feitos, cabe agora informar que do ponto de vista metodológico, este trabalho foi construído a partir da pesquisa documental, através da realização de um levantamento de legislações, resoluções e pareceres que perpassam o Ensino Religioso tanto a nível nacional, quanto a nível estadual. Este tipo de pesquisa, tem como característica coletar conteúdos textuais no qual será desenvolvido o processo investigativo e analítico (SEVERINO 2007). E, complementando esta prática também utilizei a pesquisa bibliográfica para trabalhar com outras produções acadêmicas serviram de subsídio através de seus dados e categorias já apresentadas (SEVERINO 2007).

\footnotetext{
${ }^{2}$ Para quem tiver interesse, sugiro conhecer o livro intitulado "O Ensino Religioso no Brasil", organizado por Sérgio Junqueira e que é uma leitura obrigatória para quem deseja conhecer a história desta disciplina.
} 
O trabalho está dividido em três tópicos, sendo o primeiro, intitulado "Legislação educacional brasileira e o Ensino Religioso" apresenta os elementos constitucionais e infraconstitucionais que moldam a disciplina Ensino Religioso, como por exemplo, o art. 210 da Constituição Federal Brasileira, o Art. 33 da Lei de diretrizes e Bases da Educação Nacional, a Lei 10.639/03, entre outros. O segundo tópico, seguindo o modelo o primeiro, apresenta um levantamento da documentação produzida pelo Estado do Amazonas que perpassa o Ensino Religioso, e, destaco aqui, as resoluções do Conselho Estadual de Educação do Amazonas sobre o perfil profissional para ministrar a disciplina, bem como, a lei estadual n 138 de 2013 que define as características do Ensino Religioso em seu sistema de educação.

O terceiro e último tópico, intitulado "Algumas considerações sobre a relação entre o Ensino Religioso e as Ciências da Religião" aponta alguns dados referentes a oferta a nível de licenciatura em Ciências da Religião por instituições públicas no Brasil, bem como aponta a alguns elementos que caracterizam a Ciências da Religião e a relação da mesma com o Ensino Religioso.

\section{LEGISLAÇÃO EDUCACIONAL BRASILEIRA E O ENSINO RELIGIOSO}

O Ensino Religioso, no que se refere aos aspectos legais, possui diversos dispositivos constitucionais e infraconstitucionais de modo a definir suas características e sua função na educação pública brasileira. O primeiro elemento está apontado no Art. 210 da Constituição Federal de 1988, que define que "serão fixados conteúdos mínimos para o ensino fundamental, de maneira a assegurar formação básica comum e respeito aos valores culturais e artísticos, nacionais e regionais" e no $\S 1^{\circ}$ informa que o "o ensino religioso, de matrícula facultativa, constituirá disciplina dos horários normais das escolas públicas de ensino fundamental", inserindo, portanto, a disciplina no hall das necessárias para garantir a formação básica dos discentes, mesmo que ela seja ofertada de forma facultativa.

Essa compreensão acerca da importância do Ensino Religioso como um elemento necessário para a formação e o respeito a diversidade nos é reforçada quando lembramos do art. $5^{\circ}$, inciso VI, que trata da inviolabilidade da liberdade religiosa e da proteção aos locais de cultos e liturgias, bem como o inciso VIII que determina que ninguém pode ter seus direitos privados por suas crenças religiosas (ou não-religiosas) - a não ser que a utilize como argumento para se eximir de obrigação legal, ou seja, não cumprir uma demanda imposta pelo Estado.

Sobre a questão do Ensino Religioso, Leis de Diretrizes e Bases da Educação Nacional (LDBEN), especificamente em seu o artigo 33 informa que: 
O ensino religioso, de matrícula facultativa, é parte integrante da formação básica do cidadão e constitui disciplina dos horários normais das escolas públicas de ensino fundamental, assegurado o respeito à diversidade cultural religiosa do Brasil, vedadas quaisquer formas de proselitismo (grifo meu).

Além do Artigo 33 da LDBEN, outras leis também influenciam diretamente no modelo de Ensino Religioso no Brasil como a Lei 10.639/03 que torna obrigatório o Ensino de História e Cultura Afrobrasileira e a Lei 11.645/08, que adiciona ao conteúdo da lei anterior a obrigatoriedade do ensino de história e cultura indígena, estas leis estão expressas no Art. 26-A da LDBEN:

Art. 26-A. Nos estabelecimentos de ensino fundamental e de ensino médio, públicos e privados, torna-se obrigatório o estudo da história e cultura afro-brasileira e indígena.

$\S 1^{o}$ O conteúdo programático a que se refere este artigo incluirá diversos aspectos da história e da cultura que caracterizam a formação da população brasileira, a partir desses dois grupos étnicos, tais como o estudo da história da África e dos africanos, a luta dos negros e dos povos indígenas no Brasil, a cultura negra e indígena brasileira e o negro e o índio na formação da sociedade nacional, resgatando as suas contribuições nas áreas social, econômica e política, pertinentes à história do Brasil.

$\S 2^{\circ}$ Os conteúdos referentes à história e cultura afro-brasileira e dos povos indígenas brasileiros serão ministrados no âmbito de todo o currículo escolar, em especial nas áreas de educação artística e de literatura e história brasileiras.(grifo meu)

A partir da Lei 10.639/03 foi gerada uma diretriz curricular para nortear a efetivação dessa legislação educacional, trata-se das Diretrizes Curriculares Nacionais para a Educação das Relações Étnico-Raciais e para o Ensino de História e Cultura Afro-brasileira e Africana (DCNERER).

O DCNERER (2004, p.12) aponta a cultura religiosa de matriz africana presente no Brasil como um dos componentes a serem abordados em vista a valorização e desconstrução de preconceitos historicamente impostos a estas, bem como aos seus adeptos:

Reconhecer exige a valorização e respeito às pessoas negras, à sua descendência africana, sua cultura e história. Significa buscar, compreender seus valores e lutas, ser sensível ao sofrimento causado por tantas formas de desqualificação: [...] fazendo pouco das religiões de raiz africana.

A temática da religião também está presente na diretriz curricular sobre Educação em Direitos Humanos, quando a mesma trata da laicidade do Estado, do respeito a diversidade religiosa e do respeito a não-crença como um dos elementos basilares da educação voltada para os direitos humanos (Diretrizes Curriculares Nacionais Gerais para a Educação Básica (2013).

O último documento a nível nacional sobre o Ensino Religioso tenta resolver uma questão histórica para a disciplina que é a formação para o exercício da docência. A LDB havia definido que os sistemas de ensino estabeleceriam as normas para admissão de professores (Art. 33, § $1^{\circ}$ ), o que 
levou na prática, a disciplina ter uma pluralidade de formações profissionais aptas para lecionar. No entanto, no ano de 2018, o Conselho Nacional de Educação através do parecer $\mathrm{n}^{\mathrm{o}} 12$ definiu a licenciatura em Ciências da Religião como a formação inicial para a docência da disciplina Ensino Religioso na Educação Básica ${ }^{3}$.

\section{ASPECTOS LEGAIS DO ENSINO RELIGIOSO NA REDE ESTADUAL DE EDUCAÇÃO DO AMAZONAS}

Sobre a docência no Ensino Religioso na rede estadual de educação do Amazonas pude encontrar três resoluções do Conselho Estadual de Educação do Amazonas, uma do ano de 2001 e duas no ano de 2010. A primeira é a resolução nº 108 de 2001 que definia a Licenciatura em Ensino Religioso ou na ausência de pessoas com essa formação poderiam ser admitidas pessoas com especialização em Ensino Religioso ou ainda qualquer licenciatura na área de Ciências Humanas e que tenham feito algum curso de no mínimo 120 sobre Ensino Religioso.

No ano de 2010 há duas resoluções, a primeira é a resolução $\mathrm{n}^{0}$ 76/10 e a segunda é a resolução no 97/10. Entre as duas não existe diferença de seus conteúdos o que por si só já causa estranhamento, pois existe fizeram duas resoluções como o mesmo conteúdo, no entanto, há diferenças significativas entre essas e a resolução de 2001 e me atentarei especificamente neste ponto sobre o perfil profissional.

As resoluções 76 e 97 definem que devem ter diploma de habilitação de magistério em nível médio, ou licenciatura em qualquer área do conhecimento ou ainda pode ser um bacharel que cursou algum programa de complementação pedagógica, além disso, o profissional deveria ter um curso de extensão universitária, atualização ou de aperfeiçoamento com no mínimo 180h em religião ${ }^{4}$ ou pósgraduação de no mínimo $360 \mathrm{~h}$, em ambos os casos, estes devem ser devidamente reconhecidos pelo MEC.

As resoluções do ano de 2010 sugerem um retrocesso na formação dos professores aptos a lecionar esta disciplina, pois se antes era necessário prioritariamente ter formação em Ensino Religioso em nível de licenciatura e na ausência desse profissional poderia ministrar pessoas com licenciadas nas áreas das ciências humanas e que tiveram algum curso de formação específica em Ensino Religioso.

${ }^{3} \mathrm{O}$ debate sobre essa questão da formação inicial em Ensino Religioso é bem extensa e o aprofundamento fugiria da ideia inicial deste texto.

${ }^{4}$ Termo utilizado na resolução 
Com a nova resolução o docente com extinta formação de magistério pode lecionar, assim como também abre possibilidade para licenciados em física ou em informática, por exemplo, possam também estarem aptos. Para todas essas situações basta que qualquer um deles tenha pelo menos um curso de 180 que pode ser de aperfeiçoamento, atualização ou de extensão universitária em religião, uma especificação bem genérica que nada esclarece e atualmente com a diversidade de formações nesses níveis aceitas pelo MEC não garante que a pessoa obterá a devida formação para direcionar a disciplina a partir dos dispositivos legais.

No ano de 2013, foi promulgada a lei n n $^{138 / 13}$ sobre o Ensino Religioso no sistema de ensino do Amazonas, nela o artigo art. 8 define que:

O exercício da docência do Ensino Religioso na rede pública estadual de ensino fica reservado a integrantes efetivos do quadro do Magistério da Secretaria de Estado da Educação - SEDUC, garantida a isonomia salarial e que atenda a um dos seguintes requisitos:

I - Diploma de Licenciatura Plena em Ensino Religioso, Ciências da Religião ou Educação Religiosa;

II - Diploma de Licenciatura em Pedagogia, com habilitação para o magistério de $1^{\circ}$ ao $5^{\circ}$ ano do ensino fundamental;

III - Diploma de Licenciatura em qualquer área do conhecimento com curso de especialização Lato-sensu ou Strictu-sensu, em Ensino Religioso, em Ciências da Religião ou equivalente;

IV Diploma de Bacharel em Teologia com complementação pedagógica nos termos da resolução 02/97 do Plenário do Conselho Nacional de Educação.

Apesar dessa lei apontar de forma prioritária o exercício da docência a partir de formação específica em Ensino Religioso, Ciências da Religião, ou educação religiosa, a mesma ainda assegura que as diversas licenciaturas a também pleitear a vaga, desde que tenha pós-graduação em Ensino Religioso, ou em Ciências da Religião e ainda o teólogo, desde que tenha complementação pedagógica.

Quando comparado com a resolução do Conselho Estadual de Educação do Amazonas, notase um sensível avanço ao priorizar cursos de Ciências da Religião e mesmo quando aberto as diversas licenciaturas, está sob a condição de ter cursado especialização, mestrado ou doutorado em Ensino Religioso, Ciências da Religião, ou equivalente, apesar do Brasil não ter até o momento um doutorado específico para o Ensino Religioso.

Outro ponto a ser destacado é a questão dos teólogos com complementação pedagógica que mais uma vez traz a discussão da confessionalidade do ensino, apesar da legislação atual ser terminantemente contrária fica a pergunta se os cursos de teologias têm formação que adequada para tratar das diversas religiões e não somente de uma. 
A fim de exemplificar como essas legislações e portarias operaram na prática, é preciso dizer que no ano de 2018 o Governo do Estado do Amazonas publicou no mês de abril um edital de concurso público ${ }^{5}$ para a docência e entre as disciplinas contempladas estava o Ensino Religioso e nele constava que era possível assumir o cargo desde que com licenciatura em qualquer área do conhecimento desde que tivessem em sua formação algum curso em religião, seja de aperfeiçoamento, atualização ou extensão universitária com no mínimo 180h, ou curso de pósgraduação com no mínimo 360h, reconhecidos pelo $\mathrm{MEC}^{6}$.

Na prática o que estava sendo requerido eram as definições da resolução publicada em 2010 pelo Conselho Estadual de Educação e não a lei no 138 de 2013 que apesar das críticas que podem ser feitas está mais próxima das legislações nacionais, bem como do parecer do Conselho Nacional de Educação já citado que foi feito no ano de 2018.

Observando agora as características da disciplina definidas pelo Estado, tem-se na constituição estadual, especificamente a alínea J do inciso II, art. 199 que o Ensino Religioso é "aberto a todos os credos". Apesar dessa redação ter um caráter bastante genérico e bem menos explicativo que o expresso no art. 33 da LDBEN, o mesmo demonstra que não haveria nenhum tipo de limitação no que se refere a abordagem da diversidade religiosa em sala de aula.

No entanto, ele também não reafirma o compromisso com a LDBEN no tocante a defesa contra o proselitismo, bem como não expressa que a disciplina deve ser construída tendo a diversidade religiosa como norte, uma vez que "aberto a todos os credos" não define que necessariamente se abordará pelo menos mais de uma religião, ou seja, na perspectiva colocada acaba abrindo margem para o confessional.

O Ensino Religioso só vai ser mais bem descrito na já referida lei $n^{\circ}$ 138/13 que aponta no parágrafo único que no Ensino Religioso se "respeitará a diversidade cultural e religiosa do Brasil, sendo vedadas quaisquer formas de discriminação, proselitismo e de abordagens de caráter confessional.

Outro artigo a ser destacado nessa perspectiva é o art. 4 ao definir que o "Ensino Religioso será ministrado de forma a incluir aspectos da religiosidade em geral, da religiosidade brasileira e regional, da fenomenologia da religião, da antropologia cultural e filosófica, e da formação ética". Um importante ponto a ser observado é que o referido artigo sugere que está utilizando o termo

\footnotetext{
${ }^{5}$ Edital disponível em: <http://www.educacao.am.gov.br/wp-content/uploads/2018/05/Edital-01-NIVELSUPERIOR.pdf>. Acesso em: 02/09/2020

${ }^{6}$ Descrição do cargo no edital disponível em: <http://www.educacao.am.gov.br/wp-content/uploads/2018/05/ANEXODO-EDITAL-01-NIVEL-SUPERIOR.pdf>. Acesso em 02/09/2020
} 
"religiosidade" para aludir as denominações religiosas, apontando que o Ensino Religioso deve abordar em diferentes escalas a composição da diversidade religiosa.

Ainda nessa mesma lei, o art. 6 discorre:

Os conteúdos programáticos da disciplina Ensino Religioso devem ser organizados dentro dos seguintes eixos:

I - Antropologia das Religiões: o fenômeno religioso é entendido como construção cultural da humanidade, manifestada por meio de crenças e religiões, que interagem com o cotidiano por ela vivido e produzido.

II - Sociologia das Religiões: o fenômeno religioso é estudado do ponto de vista dos aportes e conflitos civilizatórios, criados por sociedades humanas, formados por experiências de diferentes crenças.

III - Filosofia das Religiões: o fenômeno religioso é tratado como manifestação ética da humanidade e como forma de compreensão do vivido, assim como da destinação humana, por meio das divindades, dos textos sagrados, das espiritualidades.

IV - Psicologia das Religiões: o fenômeno religioso é compreendido a partir dos acontecimentos vividos pelo homem.

V - Literatura sagrada e símbolos religiosos: referem-se aos livros sagrados das religiões monoteístas e também orais, culturais e simbólicas, dos cultos afrobrasileiros de matriz africana e dos indígenas brasileiros. (grifo meu)

A referida legislação incorpora as demandas das leis 10.639 e 11.645/08 de forma explícita ao elencar as experiências religiosas de matriz africana e as indígenas como um dos assuntos a serem contemplados no Ensino Religioso e também está em diálogo com as resoluções nº89/07 e n 75/107

Enquanto a primeira trata da incorporação de conteúdos relacionados a história e cultura afro-brasileira em todas as disciplinas (Art. $6^{\circ}, \S 1^{\circ}$ ) do Sistema de Ensino do Estado do Amazonas, a segunda resolução aprovada em 2010 é para efetivar a 11.645/08 que preconiza o estudo da história e cultura indígena (Art. 1 e Art. $2, \S 1^{\circ}$ e $\S 2^{\circ}$ ).

\section{ALGUMAS CONSIDERAÇÕES SOBRE A RELAÇÃO ENTRE O ENSINO RELIGIOSO E AS CIÊNCIAS DA RELIGIÃO}

As considerações que aqui seguem, estão norteadas pelo parecer $n^{\circ} 12 / 2018$ que define a licenciatura em Ciências da Religião como área de formação do professor habilitado para ministrar a disciplina Ensino Religioso, nesse sentido, as ideias apresentadas se debruçam sobre os aspectos formativos a partir de duas perspectivas diferentes, mas extremamente interligadas, a saber: a importância da formação para o exercício da docência e o quadro de oferta da licenciatura em Ciências

\footnotetext{
${ }^{7}$ Ambas as resoluções estão disponíveis em: < http://www.cee.am.gov.br/?option=com_phocadownload\&view=category\&id=18:2007\&Itemid=194>. Acesso em 27/09/20.
} 
da Religião e seus impactos no campo do Ensino Religioso nas escolas públicas. Esclarecido os objetivos desse tópico, o primeiro ponto a ser ressaltado é que o referido parecer responde primeiramente a uma demanda imposta pela própria LDBEN, em seu artigo 62 que preconiza que "a formação de docentes para atuar na educação básica far-se-á em nível superior, em curso de licenciatura plena $[\ldots] "$.

Outro ponto que é importante esclarecer se refere a associação entre as Ciências da Religião e o Ensino Religioso ainda precisar ser mais difundido e conhecido, pois não podemos desconsiderar que ainda é bem recente o parecer $n^{\circ} 12 / 2018$ do CNE e a discussão sobre essa temática é muito mais familiar para quem tem interesse no tema, sendo, portanto, estranho a população de modo geral e para profissionais da educação que não estão atento a essa discussão e não podemos esquecer, claro, da trajetória das duas áreas, em especial a do Ensino Religioso, como já sugere RODRIGUES (2015, p. 56) ao dizer que:

A relação entre Ciência da Religião e Ensino Religioso não é auto-evidente, embora o objeto das duas seja a religião [...] a Ciência da Religião na academia brasileira teve início com estudos que priorizaram o empírico como, em certo sentido, o Ensino Religioso, que, antes de um embasamento teórico e compreensivo sobre a religião, teve início pelas mãos de profissionais envolvidos mais com a vivência dela do que com a reflexão a seu respeito.

Ao se falar em Ciências da Religião me reporto a uma área recente no Brasil, com seu surgimento datado em 1969 a partir da criação do colegiado de Ciências das Religiões instalados no interior da Universidade Federal de Juiz de Fora (JUNQUEIRA 2012; PIEPER 2019) e que levaria a criação do Departamento de Ciências da Religiões em 1971 (JUNQUEIRA 2012), portanto, estamos falando de uma área que institucionalmente fará 50 anos em 2021. A oferta de formação na área de Ciências da Religião a nível de graduação e pós-graduação ocorreu de maneira distinta, sendo a formação strictu sensu, pois a primeira a ser formalmente apresentada com regularidade foi a oferta de pós-graduação com a especialização em Ciência da Religião em 1991 e em 1993, o mestrado, ambos na UFJF (JUNQUEIRA 2012), enquanto primeira licenciatura em Ciências da Religião só surgiria no ano de 1999 na Universidade do Estado do Pará (PIEPER 2019).

De todo modo, Pieper $(2019$, p.40) nos aponta esses dois caminhos trilhados pela Ciências da Religião:

[...] a inserção das Ciências da Religião nas universidades públicas se dá a partir de dois modelos. As primeiras licenciaturas têm início a partir de demandas práticas de formação de professores para o Ensino Religioso, tendo forte acento prático. Dada sua história peculiar, o desafio enfrentando por esse modelo é desenvolver compreensão de Ensino Religioso e de formação de professores que não recaia em modelos confessionais ou proselitistas. No segundo modelo, recorrente em 
universidades federais, os cursos surgem a partir de iniciativas de professores de outras áreas do saber, mas com interesse na pesquisa sobre religião.

Sem querer delongar muito sobre a trajetória das Ciências da Religião no $\mathrm{Brasil}^{8}$, o importante é perceber que a oferta da formação específica é bem recente mesmo se considerarmos a pós-graduação, também é importante perceber que as mesmas surgem por motivações diferentes. Enquanto a licenciatura ganha fôlego pelo interesse de responder a necessidade de formação adequada para ministrar a disciplina Ensino Religioso, a pós-graduação é uma consequência do interesse acadêmico pelo estudo da religião.

A título de conhecimento, no Brasil, segundo PIEPER (2019) há oito instituições públicas, federais ou estaduais, que ofertam a Licenciatura em Ciências da Religião, a saber, por ordem cronológica: Universidade do Estado do Pará (1999), Universidade do Estado do Rio Grande do Norte (2001), Universidade Estadual de Montes Claros (2007), Universidade Federal da Paraíba (2011), Universidade Federal do Sergipe (2011), Universidade Federal de Juiz de Fora (2012), Universidade Estadual do Amazonas (2015), Universidade Federal Santa Maria (2016). Apesar, do autor apontar o Estado do Amazonas como um pólo de formação a nível de Licenciatura em Ciências da Religião, na prática, o que houve foi a oferta de apenas uma turma através do Plano Nacional de Formação de Professores (PARFOR), portanto, não sendo uma oferta regular dessa formação.

Face ao exposto, se tem no Brasil a oferta dessa licenciatura em quatro universidades federais e em três estaduais, desconsiderando a oferta excepcional da Universidade Estadual do Amazonas, sem esquecermos que na Universidade Federal Santa Maria a oferta é em regime de Educação à Distância (EAD), como indicado no portal eletrônico da instituição ${ }^{9}$. Posto essas informações, já fica subentendido o desafio para a oferta da referida formação a nível nacional.

Diante desse cenário, quer a nível nacional, ou a nível estadual, alguns desafios se impõem para aqueles e aquelas que ministram a disciplina, possuindo ou não, a formação em Ciências da Religião. A título de exemplo, como o próprio trabalho sugere, é a necessidade de conhecer os dispositivos legais que direta ou indiretamente perpassa o Ensino Religioso, pois essa ação poderia possibilitar a desconstrução dessa relação ainda presente na memória de professores que acabam relacionando a disciplina com práticas confessionais, no sentido de utilizá-la como instrumento de catequização, experiência essa já superada pelo menos desde a constituição de 1988 do ponto de vista

\footnotetext{
${ }^{8}$ Para conhecer de forma mais detalhada esse processo, sugiro a leitura dos artigos de Sérgio Junqueira e Frederico Pieper em que as informações foram utilizadas para a formulação deste trabalho, respectivamente intitulados "O processo de gênese da (s) ciência (s) da religião na UFJF" e "Ciências da Religião nas universidades públicas brasileiras: modelos de implementação e desafios". Ambos estão na bibliografia deste artigo.

${ }^{9}$ Link: <https://www.ufsm.br/graduacao/>. Acesso em 28/11/2020.
} 
legal, sendo este entendimento consagrado pela LDBEN. Sobre a superação dessa compreensão acerca do Ensino Religioso, RODRIGUES (2013, p. 230) aponta:

A despeito do Ensino Religioso (ER) no Brasil ter sido oferecido desde o período colonial sob os auspícios da Igreja Católica, conforme a orientação jesuítica e com finalidade especificamente proselitista e evangelizadora, a discussão sobre esse componente da grade curricular[...] não deveria se pautar pelo lastro histórico de confessionalidade, pois já existem modalidades de oferta dessa disciplina que negam o privilégio de qualquer discurso religioso, em favor de uma proposta que visa à compreensão da diversidade e preservação do pluralismo de ideias e de crenças religiosas.

Fica evidente, portanto, que a formação em Ciências da Religião é aquela que possibilita efetivar os dispositivos legais, por possibilitar ao docente os conhecimentos teóricos e metodológicos para tratar do religioso em sala de aula sem fazer disso uma prática prosélita, ação que é expressamente vedada no art. 33 da LDBEN. Isso posto, é importante perceber que esta afirmação sobre a necessidade de formação específica para exercer a docência não é novidade nenhuma, pois para ministrar disciplinas como Língua Portuguesa, História, Filosofia, etc., é pressuposto base que o profissional seja formado nas respectivas áreas, no caso exemplificado: Letras, História e Filosofia, acompanhada de uma formação pedagógica adequada para que esse profissional consiga alcançar os objetivos escolares almejados e esse requisito também está imposto ao exercício da docência do Ensino Religioso. O profissional deve ter formação específica para atender o que dela se espera a partir de sua especificidade disciplinar e da legislação educacional.

A fim de que se conheça um pouco mais da história da oferta de Ensino Religioso, PASSOS (apud SOARES 2009, p. 8) informa:

O modelo catequético é o mais antigo; está relacionado, sobretudo, a contextos em que a religião gozava de hegemonia na sociedade, embora ainda sobreviva em muitas práticas atuais que continuam apostando nessa hegemonia, utilizando-se, pior sua vez, de métodos modernos. Ele é seguido do modelo teológico que se constrói num esforço de diálogo com a sociedade plural e secularizada e sobre bases antropológicas. O último modelo, ainda em construção, situa-se no âmbito das Ciências da Religião e fornece referências teóricas e metodológicas para o estudo e o ensino da religião como disciplina autônoma e plenamente inserida nos currículos escolares. Esse visa a lançar as bases epistemológicas para o ER, deitando suas raízes e arrancando suas exigências do universo científico dentro do lugar comum das demais disciplinas ensinadas nas escolas.

As informações acima expostas, talvez sugira ao leitor uma espécie de linha evolutiva do Ensino Religioso nas escolas, e sob certo ponto de vista até é, porém, o importante é perceber que ao longo do seu desenvolvimento, a disciplina passou por mudanças de caráter epistemológico para que a mesma pudesse responder as demandas da sociedade de seu tempo. Nesse sentido, não se deve 
tomar o passado da disciplina como o elemento definidor de seu futuro, mas como um espírito de uma época.

$\mathrm{Na}$ atualidade quem ministra a disciplina deve se nortear pelas Ciências da Religião, área que possibilita a efetivação do Ensino Religioso de modo a efetivar, por exemplo, a garantia constitucional da liberdade religiosa e da não-crença que consiste tanto na segurança do sujeito religioso viver a sua fé como também daquele que se entende como um não-crente, nesse sentido, PIEPER (2019, p. 34) ao abordar a o Ensino Religioso a luz das Ciências da Religião, aponta que "a justificativa para seu ensino não é propriamente religiosa, mas política e social: formar cidadãos habilitados para o diálogo e atuação numa sociedade democrática" ao possibilitar ao educando, de acordo com SOARES (2009, p. 10) a aprender que "nenhum sistema de referencia pode ou deve reclamar para si a validade absoluta".

Uma dúvida que pode pairar no leitor até esse ponto e que não foi discutido que é sobre a especificidade das Ciências da Religião como área de conhecimento e sem querer adentrar de forma mais detida a uma reflexão epistemológica que é demasiadamente importante, porém, fugiria totalmente da proposta dessa comunicação, uma vez que há um extenso debate epistemológico sobre o mesmo. de todo modo, estou apontando um campo científico que no Brasil se constituiu através da interdisciplinaridade (FERREIRA e SENRA 2012) que tem como objeto central a religião, o estudo da religião, nesse sentido, estou falando de uma área que mais se caracteriza pelo objeto de estudo do que por um aporte teórico e metodológico característico.

A esse respeito, JÚNIOR e PORTELLA (2012, p. 445) afirmam que nas Ciências da Religião:

[...] importa não privilegiar nem uma abordagem que se queira descobridora de uma religião substancial, nem a que vise só as funções da religião na sociedade e cultura, ou psique; mas fazer estas duas perspectivas dialogarem criativamente e polinizaram-se, ainda que não se proponha um sincretismo metodológico.

Obviamente que essa discussão de cunho mais epistemológico no campo das Ciências da Religião não está resolvida da forma como exponho minhas compreensões a respeito dessa área até porque é característica do científico está em constante processo de crítica para o aperfeiçoamento dos elementos que o constitui, seja do ponto de vista teórico, metodológico ou epistemológico. No entanto, a proposta da exposição dessas ideias consiste em fazer conhecer um pouco das características das Ciências da Religião e assim perceber suas especificidades e no que ela se diferencia em relação as outras áreas. 
Sendo o religioso, um elemento multifacetado, possuindo em seu interior aspectos objetivos e subjetivos (RODRIGUES 2013), que podem ser vislumbrados tanto do ponto de vista histórico como também ao realizar uma pesquisa de campo em uma grande metrópole, ou em uma pequena cidade do interior de qualquer Estado brasileiro do sul ou do norte, portanto, trata-se de um "objeto vivo" na sociedade brasileira. Face ao exposto, fica compreendido que é através do diálogo entre teorias e métodos que se configuraria a empresa de um cientista da religião sobre o "objeto" de interesse, portanto, no campo das Ciências da Religião "tensões pelo melhor lugar de fala sobre a religião são algo improfícuo" (CONCEIÇÃO 2011, p. 894), uma vez que torna-se preocupação do fazer científico desta área a construção de análises que não redundem em uma "objetividade extrema" ou "dogmatização absoluta dos conteúdos" religiosos, como pondera CONCEIÇÃO (2011).

\section{CONSIDERAÇÕES FINAIS}

Ao considerar a natureza preliminar deste trabalho que se caracterizou como um ponto de partida para conhecer as particularidades da oferta do Ensino Religioso no Estado do Amazonas, privilegiando com isso adentrar nas questões legais que norteiam o fazer dessa disciplina tanto a nível nacional, quanto a nível estadual por entender que estes dados são elementos chaves para compreender a situação atual desta disciplina, entendo que as "considerações finais" do trabalho muito mais do que fechar a discussão, dever ser utilizada para apontar elementos que precisam investigados e por consequência, objetos de produções futuras.

A formação dos professores que ministram a disciplina, o currículo do Ensino Religioso, a forma como vem sendo ministrada, as dificuldades relacionadas a execução dela, a percepção dos alunos sobre a mesma, bem como, conhecer a produção academia local sobre a temática e a formação proposta em Ciências da Religião pela Universidade Estadual do Amazonas são questões que precisam ser conhecidas, enfim, há um campo a ser desvelado.

Especificamente sobre os resultados dessa primeira aproximação com o campo a partir dos elementos legais, fica evidente que o Ensino Religioso se distanciou sensivelmente do seu passado confessional, evangelizador, sendo o esforço atual de efetivar, de tornar prático o que a legislação educacional preconiza. Volto a ressaltar que apenas a formalidade não basta, se não vem acompanhada de sua efetivação e sem dúvida, a falta da oferta regular da Licenciatura em Ciências da Religião por instituições públicas de nível superior no Estado do Amazonas, certamente é um entrave, no entanto, o parecer n. 12/2018 do Conselho Nacional de Educação aponta para mudanças que provavelmente não virão na velocidade desejada. No entanto, a realidade atual não pode ser 
considerada determinante para supor um retorno ao passado confessional e nem a perpetuação do presente, que apesar das conquistas, é insatisfatório e não atende os requisitos legais de oferta da disciplina. É importante frisar que essa problemática não é uma realidade exclusiva do Amazonas, mas do Brasil.

\section{Referências}

AMAZONAS. Conselho Estadual de Educação. Resolução $\mathrm{n}^{0} 108$ de 2001. Disponível em: $<$ http://www.cee.am.gov.br/?option=com_phocadownload\&view=category\&id=13:2001\&Itemid=1 94\#>. Acesso em: 27/09/2020.

. Conselho Estadual de Educação. Resolução $n^{0} 89$ de 2007. Disponível em: $<\mathrm{http}$ //www.cee.am.gov.br/?option=com_phocadownload\&view=category\&id=18:2007\&Itemid=1 94>. Acesso em: 27/09/2020.

Conselho Estadual de Educação. Resolução $n^{\circ} 75$ de 2010. Disponível em: $<\mathrm{http}$ //www.cee.am.gov.br/?option=com_phocadownload\&view=category\&id=21:2010\&Itemid=1 94>. Acesso em: 27/09/2020.

. Conselho Estadual de Educação. Resolução $\mathrm{n}^{\mathrm{o}} 76$ de 2010. Disponível em:

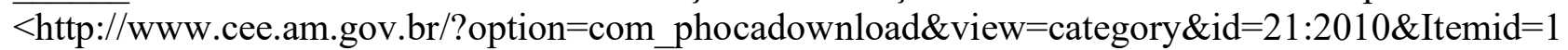
94>. Acesso em: 27/09/2020.

. Conselho Estadual de Educação. Resolução no 97 de 2010. Disponível em: $<\mathrm{http}: / /$ www.cee.am.gov.br/?option=com_phocadownload\&view=category\&id=21:2010\&Itemid=1 94>. Acesso em: 27/09/2020.

Lei 138 de 17 de Março de 2013. Disponível em:

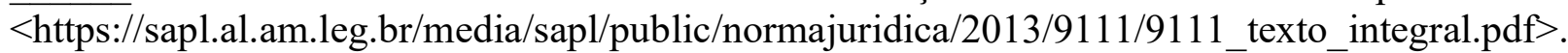
Acesso em: 27/09/2020.

BRASIL. Constituição Federal de 1988. Bloch Editores S.A. Rio de Janeiro: s/a.

BRASIL. Conselho Nacional de Educação. Parecer no 12/2018. Disponível em: $<$ http://portal.mec.gov.br/index.php?option=com_docman\&view=download\&alias=99971-pcp01218\&category_slug=outubro-2018-pdf-1\&Itemid=30192>. Acesso em: 28/11/2020.

. Diretrizes Curriculares Nacionais Gerais para a Educação Básica. Brasília: MEC, SEB, $\overline{\text { DICEI, }} 2013 . \quad$ Disponível em: $<\mathrm{http}$ ://portal.mec.gov.br/index.php?option=com_docman\&view=download\&alias $=13448$ diretrizes-curiculares-nacionais-2013-pdf\&Itemi $\bar{d}=30192>$. Acesso em: 28/09/2020. 
. Diretrizes Curriculares Nacionais para a Educação das Relações Étnico-Raciais e para o Ensino de História e Cultura Afro-Brasileira e Africana. Brasília: MEC- SECAD/SEPPIR /INEP, 2004. Disponível em: <http://www.acaoeducativa.org.br/fdh/wp-content/uploads/2012/10/DCN-sEducacao-das-Relacoes-Etnico-Raciais.pdf>. Acesso em: 28/09/2020.

Lei 10.639 de 9 de Janeiro de 2003. Disponível em:

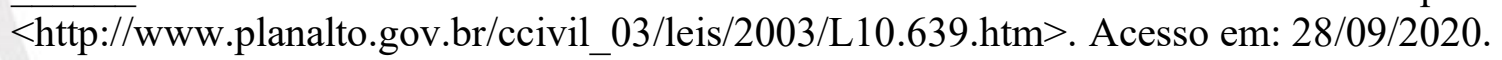

Lei 11.645 de 10 de Março de 2008. Disponível em: http://www.planalto.gov.br/ccivil_03/_ato2007-2010/2008/lei/111645.htm>. Acesso em: 28/09/2020.

. Lei de Diretrizes e Bases da Educação Nacional - LDB no 9394/96. Disponível em: $\overline{<\mathrm{http}: / / w w w . p l a n a l t o . g o v . b r / c c i v i l \_03 / L e i s / L 9394 . h t m>. ~ A c e s s o ~ e m: ~ 28 / 09 / 2020 . ~}$

CONCEIÇÃO, Douglas Rodrigues. A religião em cena: perspectivas de investigação. Revista Horizonte, Belo Horizonte, v.9, n.23, p. 883-896, out./dez. 2012. Disponível em: < http://periodicos.pucminas.br/index.php/horizonte/article/view/P.2175-5841.2011v9n23p883>. Acesso em 08/12/2020.

FERREIRA, Amauri Carlos; SENRA, Flávio. Tendência interdisciplinar das Ciências da Religião no Brasil. O debate epistemológico em torno da interdisciplinaridade e o paralelo com a constituição da área no país. Numen: revista de estudos e pesquisa da religião, Juiz de Fora, v. 15, n. 2, 2012. Disponível em: < https://periodicos.ufjf.br/index.php/numen/article/view/21852>. Acesso em 08/12/2020.

HUFF JÚNIOR, Arnaldo Érico; PORTELLA, Rodrigo. Ciência da Religião: uma proposta a caminho para consensos mínimos. Númem: revista de estudos e pesquisa da religião, Juiz de Fora, v.15, n.2, 2012. Disponível em: < https://periodicos.ufjf.br/index.php/numen/article/view/21847>. Acesso em $08 / 12 / 2020$.

JUNQUEIRA, Sérgio. O processo de gênese da(s) ciência(s) da religião na UFJF. Numen: revista de estudos e pesquisa da religião, Juiz de Fora, v. 15, n. 2, p. 537-550, 2012. Disponível em: < https://periodicos.ufjf.br/index.php/numen/article/view/21876>. Acesso em 08/12/2020.

PIEPER, Frederico. Ciências da Religião nas universidades públicas brasileiras: modelos de implementação e desafios. Rever, São Paulo, v. 19., n.2., mai/ago 2019. Disponível em: $<$ https://revistas.pucsp.br/index.php/rever/article/view/45147/29885>. Acesso em: 28/11/2020. 
RODRIGUES, Elisa. Ciência da Religião e Ensino Religioso. Efeitos de definições e indefinições na construção dos campos. Rever, São Paulo, ano 15, n.2., jul/dez 2015. Disponível em: $<$ https://revistas.pucsp.br/index.php/rever/article/view/26184/18848>. Acesso em 28/11/2020.

RODRIGUES, Elisa. Questões epistemológicas do Ensino Religioso: uma proposta a partir da Ciência da Religião. Interações - Cultura e comunidade, Belo Horizonte, v.8., n.14., jul/dez 2013. Disponível em: $\quad<$ http://periodicos.pucminas.br/index.php/interacoes/article/view/P.19838478.2013v8n14p230/6245>. Acesso em: 28/11/2020.

SEVERINO, Antonio Joaquim. Metodologia do trabalho científico / Antonio Joaquim Severino. - 23. ed. rev. atual, - São Paulo: Cortez, 2007. Disponível em: < https://edisciplinas.usp.br/pluginfile.php/3480016/mod_label/intro/SEVERINO_Metodologia_do_T rabalho_Cientifico_2007.pdf>. Acesso em: 27/11/2020.

SOARES, José Maria Ligório. Ciência da Religião, Ensino Religioso e formação docente. Rever, ano 9, n. 3., set. 2009. disponível em: <https://www.pucsp.br/rever/rv3_2009/t_soares.htm>. Acesso em: 28/11/2020. 